\title{
The effect of pharmacist-led education on the quality of life of children with familial Mediterranean fever
}

\begin{abstract}
Familial Mediterranean Fever (FMF) is generally defined with short endurance, suddenly observed fever $\left(39-40^{\circ} \mathrm{C}\right)$ and painful abdomen, joints, chest. The aim is to measure the impact of pharmacist-led education on the quality of life $(\mathrm{QoL})$ of children with FMF. This study was carried out in the Pediatric Rheumatology outpatient clinic of Istanbul Medeniyet University Ministry of Health Goztepe Research and Teaching Hospital, Istanbul. The QoL of 59 children was measured using the PedsQL 4.0 Generic Core Scale. Oral and written education about the disease and its treatment was provided and after a lag period QoL was re-evaluated. Significant improvements in QoL were recorded in the domains of physical, psychosocial and school functioning $(\mathrm{p}<0.05)$; and in the emotional functioning of patients with more severe attacks. These improvements were only found to be significant after a lag period of more than fourweeks. Findings suggest that the medium term benefits of education on QoL may be more important than shorter term gains. Additionally, prescribed doses were observed to be lower than optimal doses which may lead to inadequate therapy.
\end{abstract}

Volume 2 Issue 3 - 2015

\author{
Beril Kadioglu,' Mehtap Erciyes,' Serap \\ Kocsar, ${ }^{2}$ Cigdem Kaspar,' Muferet Erguven, ${ }^{3}$ \\ Caglar Macit,' Philip Clark' \\ 'Yeditepe University, Turkey \\ ${ }^{2}$ Department of Pharmacovigilance, MSD Company, Turkey \\ ${ }^{3}$ Istanbul Medeniyet University, Turkey
}

Correspondence: Caglar Macit, Faculty of Pharmacy, Yeditepe University, Atasehir, Istanbul, Turkey, Tel +90 533655459I, Fax+90216578 0068, Email cmacit@yeditepe.edu.tr

Received: April 22, 2015 | Published: May 25, 2015

Keywords: familial mediterranean fever, pharmacist-led education, quality of life, children patients

Abbreviations: FMF, familial mediterranean fever; QoL, quality of Life; PAN, polyarteritis nodosa; HSP, henoch-schönlein purpura; IL, interleukin; ASC, apoptosis-associated speck-like protein; C5a, chemotactic factor; MEFV, mediterranean fever gene

\section{Introduction}

Familial Mediterranean Fever (FMF) is characterized by short (6$96 \mathrm{~h})$, spontaneously subsiding attacks of fever $\left(39-40^{\circ} \mathrm{C}\right)$ and painful manifestations in the abdomen, joints, chest, scrotum and erysipelaslike erythema, which leave the patient bedridden during attacks. About $90 \%$ of patients experience their first attack before 20years of age. ${ }^{1,2}$ Abdominal attacks are the most common symptom, occurring in about $95 \%$ of patients. ${ }^{3}$ Articular attack is another common feature of FMF manifested by a red, swollen, warm and tender single joint. Acute mono arthritis usually appears spontaneously. ${ }^{4}$ Some types of vasculitis are more frequent in FMF, including Henoch-Schönlein purpura (HSP) and Polyarteritis nodosa (PAN). ${ }^{5}$ Physical and emotional stress, hormonal changes (estrogen reduction, menstrual cycle etc.) and some drugs (eg. cisplatin) may trigger the FMF attacks. Chronic and protracted manifestations, particularly nephropathic amyloidosis, leading to chronic renal failure, chronic arthritis and protracted myalgia, may also occur in the disease. ${ }^{1,2,5}$

The disease is transmitted in an autosomal recessive pattern and predominately affects people from the Mediterranean basin, including, Turks, Arabs, Armenians and Sephardic Jews. ${ }^{1,6}$ The overall prevalence of the disease in the Turkish population is estimated as $1 / 1,073$. However, it has been found to be as high as $1 / 395$ in central Anatolia. ${ }^{7,8} \mathrm{FMF}$ is caused by mutations in the MEFV gene, which is located on chromosome 16p13 and contains 3505 nucleotides. About 30 mutations associated with FMF have been defined, the five most common of which are M694V, M680I, M694I, E148Q and V726A, generally clustered on exon $10 .^{6,9}$ The most frequent mutation in
Turkish patients is M694V, followed by M680I and V726A. ${ }^{3}$

Daily colchicine is the conventional therapy of choice for FMF ${ }^{10,11}$ resulting in complete remission or marked reduction in the frequency, duration and severity of attacks in most patients. In an appropriate dose, it is effective at arresting and reversing renal amyloidosis. ${ }^{12}$ Colchicine improved the quality of life and laboratory results and regression of inflammation together with improvement in daily activities as observed by Ozcakar et al. ${ }^{13}$ Colchicine is believed to act on the intracellular microtubuli, thus interfering with intracellular granula transport and secretion of mediators..$^{10}$ It inhibits leukocyte chemotaxis at low concentrations and alters the expression of adhesion molecules on the surfaces of neutrophils and thus reduces their potential to produce cytokines. ${ }^{14}$ Common side effects of colchicine are diarrhea and abdominal pain, especially in higher doses. Others side effects which are extremely rare and reversible upon lowering of dose or cessation of treatment, include rash, hair loss, leukopenia, thrombocytopenia, neuropathy, myopathy, liver injury and disruption of spermatic function. ${ }^{15}$

The terms health related quality of life (QoL) refer to the physical, psychological and social domains of health that are influenced by a person's experiences, beliefs, expectations and perspectives. ${ }^{16}$ As described above, the symptoms of an FMF attack are disabling and serious long term complications are a real possible, especially if the patient's adherence to therapy is poor. There are few studies investigating the quality of life or adherence to therapy in this patient group. On the other hand, clinical trials have shown the benefits that pharmacist-led education can make to health outcomes and adherence in chronic illness. ${ }^{15,17}$ However, to date no such study has been conducted in children with FMF. The main aim of the study was to measure the effect of pharmacist-led oral and written education on the quality of life of children with FMF disease. 


\section{Material and methods}

\section{Study population and study center}

This study was a comparative, clinical study which aimed to measure the effect of education on the quality of life of young patients who have Familial Mediterranean Fever. This study was carried out in the Pediatric Rheumatology Out-patient Clinic of Istanbul Medeniyet University Ministry of Health Goztepe Research and Teaching Hospital, Istanbul, Turkey over a period of threemonths between February-May 2013. Fifty-nine patients (5-18years and Female/ Male 31/28) who were diagnosed with Familial Mediterranean Fever participated into the study. The quality of life of the patients was measured using the tool described below; following this the subjects received education by the pharmacy researchers about the disease and the drug colchicine. After a lag period of 4-12weeks the patients' QoL was reassessed. The study protocol was approved by the ethical committee of Istanbul Medeniyet University Ministry of Health Goztepe Research and Teaching Hospital, Istanbul and informed consent was obtained from all the subjects.

\section{Inclusion criteria}

Patients diagnosed with FMF between 5-18years who had been referred to the hospital's pediatric rheumatology clinic for diagnosis, treatment and follow-up were included in this study. The diagnosis of FMF was established according to the Tel-Hashomer criteria.

\section{Exclusion criteria}

Patients who were under 5years old and older than 18years old were excluded from this study. Patients who had other chronic illness, psychological and mental problems and patients not taking colchicine were also excluded.

\section{Measurements and records}

Patients' demographic data, medical history and physical examinations were recorded by the researchers. Fifty-nine patients with FMF ( 28 boys, 31 girls) with a mean age of 11.68 were enrolled into this study. Children over 7years old answered the PedsQL 4.0 core scale questionnaires ${ }^{16}$ translated into Turkish, by themselves without any help; and for children below 7years old, questions were read to the children and the answers were recorded.

\section{QoL measurement}

The 23-item PedsQL 4.0 Generic Core Scales encompass physical functioning (8 items), emotional functioning (5 items), social functioning (5 items) and school functioning (5 items). Child selfreport includes 5-7, 8-12 and 13-18years old. A 5-point Likert scale is utilized across the child self-report for ages 8-18 $(0=$ never a problem; $1=$ almost never a problem; $2=$ sometimes a problem; $3=$ often a problem; $4=$ almost always a problem). Items were reverse-scored and linearly transformed to a $0-100$ scale, so that higher scores indicate better health-related quality of life. Physical, emotional, social and school health summary scores are the same as the physical, emotional, social and school functioning subscales. To create a psychosocial health summary score, the mean was computed as the sum of the items divided by the number of items in the emotional, social and school functioning scales. To record the information about the patients (physical and clinical information) a 'Patient Information Form' was created.

\section{Educational methods}

Both verbal and written educational methods were employed. The verbal education included some simple information about FMF and its treatment. The benefits of the treatment were stressed as was the need for regular dosing. Written education concerning the disease and its treatment was conducted immediately following the oral education and took the form of an illustrated brochure in Turkish entitled 'Familial Mediterranean Fever: Patient Education Brochure'. This educational material was prepared after reviewing articles about FMF in the literature and with the guidance of pediatric rheumatologists and clinical pharmacists. In order to provide consistent and regular follow-up, a 'Follow-up Card' was created on which the patients' check-up appointments and the dose of the drug were recorded. This acted as a reminder to the patient of the need for regular medication and attendance at the out-patient clinic.

\section{Statistical analysis}

The SPSS 19 (IBM, NY, USA) software was used to compute the outcome measures. The initial measured variable was quality of life. One way ANOVA, analysis of variance was performed on the FMF patients before and after education. As a posttest Tukey analysis was applied. Additionally, in order to compare two groups each other, student t-test was performed, $\mathrm{p}<0.05$ was considered statistically significant and confidence intervals were set to 0.95 .

\section{Results}

The distribution between male and female patients was 28 male (mean age 11 \pm 3.49 ) and 31 female (mean age 12.3 \pm 2.88 ). Three distinct age groups were studied and their distribution is illustrated in Figure 1. There were 9 young children (5-7years old), 26 children (8-12years old) and 24 teenagers. The mean age for all patients was 11.68 \pm 3.2 . Among the demographic details that were recorded was the place of origin of the patients' parents. This provided information related to the regional distribution of FMF patients within Turkey, as shown in Figure 2. Table 1 shows the values and impact of FMF patient education on physical, psychosocial and school functioning irrespective of age and gender and Table 2 illustrates the positive effects of pharmacist-led education in young children (5-7years) on physical functioning. Although QoL measures increased in all functions for 8-12year old children, no statistically significant differences were recorded. In the 13-18year old age group, significant differences pre and post education were observed in physical, psychosocial and school functioning areas, are shown in Table 3.

While the patients QoL follow-up was conducted 4weeks after receiving education, improvement was only observed in social functioning $(\mathrm{p}=0.017)$. However, if follow-up continued more than 4 weeks, not only social functioning but also other 4 functioning parameters had significance as in Table 4. When (Table 5) (Table 6) are examined it can be noted that both patients with 1-3 clinical symptoms and those with over 3 symptoms show a significant improvement in QoL following the education provided. The main difference between the two sub-groups is in the emotional domain where patients with a significantly greater number of FMF related symptoms benefit from treatment. In Figure 3 the parallel graphs show the actual prescribed dose (gray) in contrast to the optimal therapeutic dose based on body weight (black). 


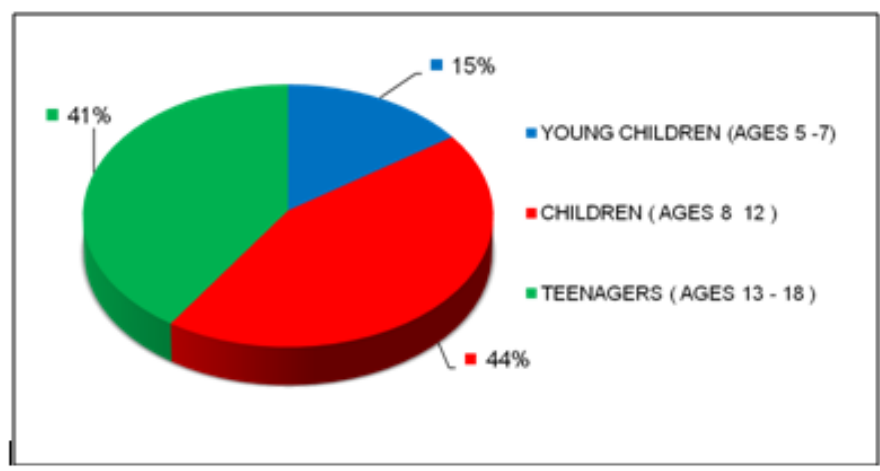

Figure I Distribution of Age Groups ( $n=59)$.

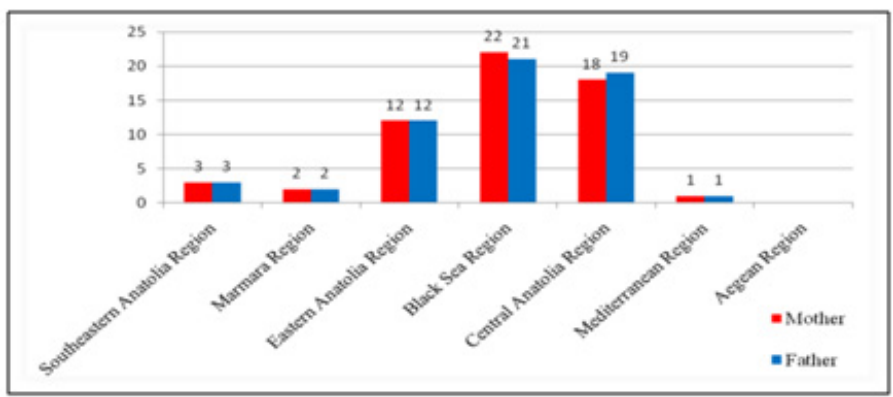

Figure 2 Distribution of patients according to Turkey's Geographical Regions.

Table I Combined QoL values and impact of Education

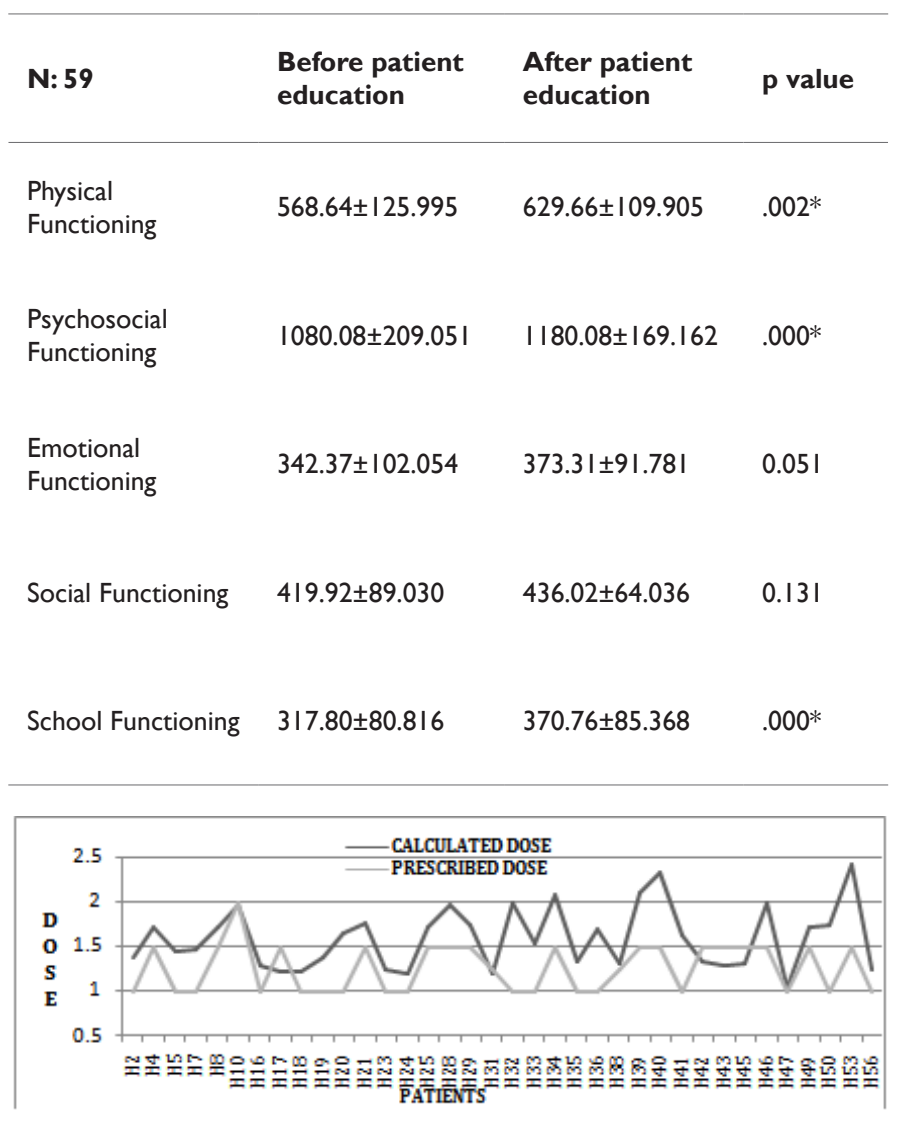

Figure $3 \mathrm{~A}$ comparison of prescribed dose and calculated optimal dose.
Table 2 Impact of education on QoL in Young Children (5-7years)

\begin{tabular}{llll}
\hline N: 9 & $\begin{array}{l}\text { Before Patient } \\
\text { Education }\end{array}$ & $\begin{array}{l}\text { After Patient } \\
\text { Education }\end{array}$ & p Value \\
\hline $\begin{array}{l}\text { Physical } \\
\text { Functioning }\end{array}$ & $522.22 \pm 134.887$ & $650.00 \pm 82.916$ & $.013^{*}$ \\
$\begin{array}{l}\text { Psychosocial } \\
\text { Functioning }\end{array}$ & $1083.33 \pm 160.078$ & $11177.78 \pm 143.856$ & 0.101 \\
$\begin{array}{l}\text { Emotional } \\
\text { Functioning }\end{array}$ & $388.89 \pm 89.365$ & $411.11 \pm 85.797$ & 0.586 \\
$\begin{array}{l}\text { Social } \\
\text { Functioning }\end{array}$ & $372.22 \pm 71.200$ & $355.56 \pm 80.795$ & 0.62 \\
$\begin{array}{l}\text { School } \\
\text { Functioning }\end{array}$ & $322.22 \pm 75.462$ & $411.11 \pm 99.303$ & 0.099 \\
\hline
\end{tabular}

Table 3 Impact of education on QoL in Teenagers (13-18years)

\begin{tabular}{llll}
\hline $\mathbf{N}: \mathbf{2 4}$ & $\begin{array}{l}\text { Before patient } \\
\text { education }\end{array}$ & $\begin{array}{l}\text { After patient } \\
\text { education }\end{array}$ & P value \\
\hline $\begin{array}{l}\text { Physical } \\
\text { Functioning }\end{array}$ & $569.79 \pm 122.470$ & $622.92 \pm 109.82 \mathrm{I}$ & $.010^{*}$ \\
$\begin{array}{l}\text { Psychosocial } \\
\text { Functioning }\end{array}$ & $1068.75 \pm 246.083$ & $\mathrm{II} 18 \mathrm{I} .25 \pm 184.487$ & $.003^{*}$ \\
$\begin{array}{l}\text { Emotional } \\
\text { Functioning }\end{array}$ & $333.33 \pm 123.725$ & $365.63 \pm 95.500$ & 0.221 \\
$\begin{array}{l}\text { Social } \\
\text { Functioning }\end{array}$ & $434.38 \pm 94.642$ & $459.38 \pm 48.237$ & 0.146 \\
$\begin{array}{l}\text { School } \\
\text { Functioning }\end{array}$ & $301.04 \pm 94.259$ & $356.25 \pm 81.51 \mathrm{I}$ & $.001 *$ \\
\hline
\end{tabular}

Table 4 QoL Values more than 4weeks after Education

\begin{tabular}{llll}
\hline $\mathbf{N}: 46$ & $\begin{array}{l}\text { Before patient } \\
\text { education }\end{array}$ & $\begin{array}{l}\text { After patient } \\
\text { education }\end{array}$ & P value \\
\hline $\begin{array}{l}\text { Physical } \\
\text { Functioning }\end{array}$ & $553.26 \pm 126.887$ & $642.39 \pm 92.176$ & $0.000^{*}$ \\
$\begin{array}{l}\text { Psychosocial } \\
\text { Functioning }\end{array}$ & $1068.48 \pm 207.193$ & $1207.07 \pm 147.823$ & $0.000^{*}$ \\
$\begin{array}{l}\text { Emotional } \\
\text { Functioning }\end{array}$ & $342.39 \pm 104.066$ & $386.96 \pm 80.232$ & $0.016^{*}$ \\
$\begin{array}{l}\text { Social } \\
\text { Functioning }\end{array}$ & $408.70 \pm 96.064$ & $439.67 \pm 66.369$ & $0.014^{*}$ \\
$\begin{array}{l}\text { School } \\
\text { Functioning }\end{array}$ & $317.39 \pm 77.972$ & $380.43 \pm 74.146$ & $0.000^{*}$ \\
\hline
\end{tabular}


Table 5 QoL values of patients with I-3 symptoms

\begin{tabular}{llll}
\hline N: 34 & $\begin{array}{l}\text { Before patient } \\
\text { education }\end{array}$ & $\begin{array}{l}\text { After patient } \\
\text { education }\end{array}$ & P value \\
\hline $\begin{array}{l}\text { Physical } \\
\text { Functioning }\end{array}$ & $576.47 \pm 128.797$ & $64 I .91 \pm 105.658$ & $0.028^{*}$ \\
$\begin{array}{l}\text { Psychosocial } \\
\text { Functioning }\end{array}$ & III9.I2 \pm 208.989 & $1203.68 \pm 165.732$ & $0.022^{*}$ \\
$\begin{array}{l}\text { Emotional } \\
\text { Functioning }\end{array}$ & $363.24 \pm 93.183$ & $378.68 \pm 91.315$ & 0.455 \\
$\begin{array}{l}\text { Social } \\
\text { Functioning }\end{array}$ & $422.06 \pm 99.955$ & $436.03 \pm 65.768$ & 0.316 \\
$\begin{array}{l}\text { School } \\
\text { Functioning }\end{array}$ & $333.82 \pm 74.844$ & $388.97 \pm 80.526$ & $0.002^{*}$ \\
\hline
\end{tabular}

Table 6 QoL values of patients with $\geq 4$ symptoms

\begin{tabular}{llll}
\hline N: 25 & $\begin{array}{l}\text { Before patient } \\
\text { education }\end{array}$ & $\begin{array}{l}\text { After patient } \\
\text { education }\end{array}$ & P value \\
\hline $\begin{array}{l}\text { Physical } \\
\text { Functioning }\end{array}$ & $558.00 \pm 123.895$ & $613.00 \pm 115.497$ & $.03 I^{*}$ \\
$\begin{array}{l}\text { Psychosocial } \\
\text { Functioning }\end{array}$ & $1027.00 \pm 201.158$ & $1148.00 \pm 171.834$ & $.005^{*}$ \\
$\begin{array}{l}\text { Emotional } \\
\text { Functioning }\end{array}$ & $314.00 \pm 108.513$ & $366.00 \pm 93.786$ & $.037^{*}$ \\
$\begin{array}{l}\text { Social } \\
\text { Functioning }\end{array}$ & $417.00 \pm 73.499$ & $436.00 \pm 62.948$ & 0.264 \\
$\begin{array}{l}\text { School } \\
\text { Functioning }\end{array}$ & $296.00 \pm 84.988$ & $346.00 \pm 87.106$ & $.018^{*}$ \\
\hline
\end{tabular}

\section{Discussion}

\section{Demographics and the effect of education on QoL}

Demographically our study does not suggest any gender differences in terms of prevalence/incidence of FMF. In addition, 85\% of the children were over 7years old (Figure 1). This may be because of the time required for patients to manifest symptoms creating enough concern to warrant further medical and genetic investigation, for the diagnosis of FMF to be made and for appropriate treatment to be initiated. The geographical distribution of patients (Figure 2), clearly indicates a higher density of cases from the central/ eastern Anatolian and Black Sea regions rather than the Mediterranean coast region itself.

It is known that the QoL of patients with FMF is lower than that of healthy controls..$^{18}$ An unpublished study which we carried out confirmed this finding in pediatric patients. Our observations in this present study, as presented in Table 1 and also in Tables 2-4, indicate that there were significant differences in QoL of children with FMF before and after education, particularly in the spheres of physical, psychosocial and school functioning. That is to say, pharmacy-led education was successful for improving the QoL of FMF patients in the spheres mentioned. This positive beneficial effect is particularly pronounced in the lives of teenagers, rather than in the younger age groups as can be seen in Tables $2 \& 3$. This might be due to a difference in maturity, older children having a greater appreciation or awareness both of the limiting effect of the disease and of the felt benefits of regular treatment. Alternatively, the effect of the disease on teenagers may be more severe and therefore they might gain more in terms of QoL from pharmacotherapy.

It was also observed that teenage boys seem to benefit significantly from health education in terms of physical function, while significant improvements were not recorded for girls of the same age. This may reflect a greater sensitivity to physical functioning among young males of this age group, as they pass through puberty.

\section{Effect of lag period}

None the domains of patients' QoL were significantly improved fourweeks following pharmacist-led health education, but by contrast, all these spheres achieved significance when the lag period was extended beyond 4weeks (Table 4). This suggests that a lag period of up to 4 weeks was not enough to demonstrate an improvement in QoL. It is possible that there may have been a time lapse between provision of health related education, the application of this information and improvements in health related quality of life. It may also be surmised that the medium term benefits of education on QoL may be more significant than the shorter term benefits. Although not within the scope of this study, investigation into the long term impact of education may prove to be a useful exercise.

\section{Impact of education on emotional health}

The only difference between the improvement in QoL of patients reporting 1-3 clinical symptoms and those patients who experienced 4-7 clinical symptoms per attack, was in terms of significantly improved emotional functioning in the latter group (Table 5) (Table 6). Patients with more severe attacks had a lower baseline QoL score in the emotional sphere. After education was provided and presumably acted upon, a significant improvement was recorded. This suggests that the sub-group with more severe attacks may particularly benefit emotionally from patient education. In a recent study conducted in Ankara, Turkey among adults with FMF it was observed that depression and anxiety were more frequent in FMF patients than in healthy subjects. ${ }^{18}$ Deger et al. ${ }^{19}$ used the SF-36 short form and the hospital anxiety and depression scale as outcome measures in the study groups. ${ }^{19}$ Both this study and our own study indicate the importance of emotional health for FMF patients.

\section{Dose of colchicine}

Therapeutic doses were based on the patients' weight in kilograms or body surface area in $\mathrm{m}^{2}{ }^{20}$ It was observed that prescribed doses were consistently lower than calculated therapeutic doses shown in Figure 3. Physicians may be prescribing over-cautiously to avoid adverse drug reactions and subsequent non-adherence. However the result of such a conservative approach may be inadequate therapy, recurrence of attacks and development of complications such as amyloidosis.

\section{Limitations of the study}

A number of limitations were observed in our study. First of all a small number of patients were included in the study and the study period was limited to fourmonths. Secondly there were a number of potential communication barriers. For example although we believe the translation was a good one, some patients encountered difficulty in understanding the terminology used in the QoL survey such as "peer" 
and "adapt". We suggest that the language should be simplified to improve comprehension, especially for 5-7year old children. Other communication barriers were encountered during the first survey and when education was being imparted. This was because it was conducted in the context of the crowded out-patient clinic where dialogue was seriously hampered.

In addition, the second QoL survey was conducted by telephone because the follow-up dates fell outside of the time frame of the study. Conducting a QoL survey over the telephone is also an imperfect communication technique. Information affecting the QoL regarding the patients' socioeconomic background was not routinely collected. This may have helped us to establish any relationship between QoL and socioeconomic conditions. The survey was a generic QoL survey; therefore the results were not disease specific. We hope to conduct a follow-up study to gain a more disease-specific or rheumatology oriented QoL measure in the different age groups. Disease-specific quality of life modules may enhance measurement sensitivity for health domains.

\section{Acknowledgements}

We were thankful to all nurses and physicians of Pediatric Department of Hospital for their help.

\section{Conflict of interest}

Author declares that there is no conflict of interest.

\section{References}

1. Petrushkin H, Stanford M, Fortune F, et al. Clinical Review: Familial Mediterranean Fever-An Overview of Pathogenesis, Symptoms, Ocular Manifestations, and Treatment. Ocul Immunol Inflamm. 2015;11:1-9.

2. The international FMF consortium. Ancient missense mutations in a new member of the RoRet gene family are likely to cause familial Mediterranean fever. Cell. 1997;90(4):797-807.

3. Tunca M, Akar S, Onen F, et al. Familial Mediterranean fever (FMF) in Turkey: results of a nationwide multicenter study. Medicine (Baltimore). 2005;84(1):1-11.

4. Sneh E, Pras M, Michaeli D, et al. Protracted arthritis in familial Mediterranean fever. Rheumatol Rehabil. 1977;16(2):102-106.

5. Flatau E, Kohn D, Schiller D, et al. Schönlein- Henoch syndrome in patients with familial Mediterranean fever. Arthritis Rheum. 1982;25(1):42-47.
6. Ben Zvi I, Herskovizh C, Kukuy O, et al. Familial Mediterranean fever without MEFV mutations: a case- control study. Orphanet J Rare Dis. 2015;10(1):34.

7. Ozen S, Karaaslan Y, Ozdemir O, et al. Prevalence of juvenile chronic arthritis and familial Mediterranean fever in Turkey: a field study. $J$ Rheumatol. 1998;25(12):2445-2449.

8. Onen F, Sumer H, Turkay S, et al. Increased frequency of familial Mediterranean fever in Central Anatolia, Turkey. Clin Exp Rheumatol. 2004;22(4 Suppl 34):S31-S33

9. Ergüven M, Emeksiz C, Deveci M, et al. Relation between microalbuminuria and gene mutations in familial Mediterranean fever. Turk $J P e$ diatr. 2008;50(4): 326-330.

10. Kastner DL. Familial Mediterranean Fever and Other Hereditary Recurrent Fevers. In: Fauci AS, editors. Harrison's Principles of Internal Medicine. New York: McGraw Hill Medical; 2005. p. 1793-1795.

11. Ozkaya N, Yalcinkaya F. Colchicine treatment in children with familial Mediterranean fever. Clin Rheumatol. 2003;22(4-5):314-317.

12. Sipe JD, Cohen AS. Amyloidosis. In: Fauci AS, editor. Harrison's Principles of Internal Medicine. 16th ed. New York: McGraw Hill Medical; 2005. p. 2024-2029.

13. Ozçakar ZB, Yalçinkaya F, Yüksel S, et al. Possible effect of subclinical inflammation on daily life in familial Mediterranean fever. Clin Rheumatol. 2006;25(2):149-52.

14. Kershenobich D, Vargas F, Garcia Tsao G, et al. Colchicine in the treatment of cirrhosis of the liver. N Engl J Med. 1988;318(26):1709-1713.

15. Gourley DR, Gourley GA, Solomon DK. Development, interpretation and evaluation of a multicentre pharmaceutical care outcomes study. $J$ Am Pharm Assoc (Wash). 1998;38(5):567-573.

16. Varni JW, Seid M, Kurtin PS. PedsQL 4.0: reliability and validity of the Pediatric Quality of Life Inventory version 4.0 generic core scales in healthy and patient populations. Med Care. 2001;39(8):800-812.

17. Clark PM, Karagoz T, Apikoglu Rabus S, et al. Effect of pharmacist- led patient education on adherence to tuberculosis treatment. Am J Health Syst Pharm. 2007;64(5):497-505.

18. Buskila D, Zaks N, Neumann L, et al. Quality of life of patients with familial Mediterranean fever. Clin Exp Rheumatol. 1997;15(4):355-360.

19. Deger SM, Ozturk MA, Demirtag MD, et al. Health- related quality of life and its association with mood conditions in Familial Mediterranean Fever. Rheumatol Int. 2011;31(5):623-628.

20. Meyerhoff Jo, Lozada CJ, Talavera F, et al. Familial Mediterranean Fever. USA: Medscape; 2015. 